\title{
ACUTE TOXICITY OF TRIBUTYLTIN ON THE MARINE COPEPOD Tisbe biminiensis
}

\author{
Bruno Varella Motta da Costa*, Gilvan T. Yogui and Lília P. Souza-Santos
}

Universidade Federal de Pernambuco - Departamento de Oceanografia

(Av. Arquitetura s/n, 50740-550 Recife, PE, Brasil)

*Corresponding author:brunovmcosta@gmail.com

http://dx.doi.org/10.1590/S1679-87592014075706201

Antifouling systems (AFS) are physical or chemical treatments that control or prevent biological fouling on submerged surfaces (IMO, 2001). Tributyltin-based compounds have been used as AFS since the 1960s. These chemicals were soon recognized as ideal biocides and became the main AFS applied to ship hulls for several decades. Champ (2001) estimated that tributyltin (TBT) was applied to approximately 60,000 vessels of the world's merchant fleet in 2001. The widespread use of TBT as an AFS was identified to be a marine pollution issue in the 1970s when oyster shell anomalies and population declines were observed in Arcachon Bay, France (ALZIEU et al., 1986). Other TBT toxic effects have been identified in marine invertebrates, including imposex in mollusks, reduced reproductive success in amphipods and biased female-to-male ratio in copepod populations (HUANG et al., 2006; AONO; TAKEUCHI, 2008; BIGATTI et al., 2009).

In 2001, the International Maritime Organization (IMO) proposed an international convention for controlling the use of harmful AFS on ships (IMO, 2001). The initial goal of banning TBT by 2008 was challenging and did not succeed. Officially, the convention came into force only on September 17, 2008 and it currently has 63 Parties whose combined fleet represents $81 \%$ of the world's merchant ships (IMO, 2012). After proposal of the AFS convention in 2001, TBT concentrations in seawater began to decline although concentrations are still considered high in some parts of the world (ANTIZARLADISLAO, 2008). Liu et al. (2011) reported seawater concentrations ranging from 17 to $274 \mathrm{ng} \mathrm{L}^{-1}$ at mariculture sites in Taiwan. Water samples collected in the vicinity of the Port of Gdnyia, Poland exhibited TBT concentrations ranging from 13 to 191 ng $\mathrm{L}^{-1}$ (RADKE et al., 2012). Martí et al. (2011) reported TBT levels of $26 \mathrm{ng} \mathrm{L}^{-1}$ in waters off the Mediterranean coast of Spain. These recent studies demonstrate that TBT concentrations in seawater still exceed the limits of 0.2 to $10 \mathrm{ng} \mathrm{L}^{-1}$ set by various regulatory agencies (CCME, 1999; CONAMA, 2005; CEC, 2006).

Copepods are particularly suitable as a role model for bioassays since they are cosmopolitan, have a short life cycle, and are easy to handle and maintain in the laboratory. However, the TBT toxicity for copepods has been estimated for just a few species such as brackish (Nitocra spinipes) and marine (Tigriopus japonicus, Tisbe battagliai) benthic species, and brackish (Eurytemora affinis) and marine (Acartia tonsa, Pseudodiaptomus marinus, Schmackeria poplesia) planktonic species (LINDEN et al., 1979; BUSHONG et al., 1988; MACKEN et al., 2008; HUANG et al., 2010).

Tisbe biminiensis is an epibenthic copepod that has been recently proposed as a model for sediment samples of tropical areas (ARAÚJOCASTRO et al., 2009). This marine species is distributed along the Atlantic coastal zone and lives associated with benthic macroalgae and sandy substrate (VOLKMANN-ROCCO, 1973). T. biminiensis cultivation in the laboratory yields high rates of population growth, and provides healthy organisms for bioassays throughout the year (RIBEIRO; SOUZA-SANTOS, 2011). Its epibenthic habit makes this species suitable for evaluation of toxicity in both water and sediment samples (ARAÚJO-CASTRO et al., 2009). The aim of this study was to assess the acute toxicity of TBT in seawater for the marine copepod $T$. biminiensis.

Neat tributyltin oxide (TBTO) was purchased from Sigma-Aldrich and used to prepare a stock solution in acetone (ACS reagent grade) at a concentration of $5.7 \mathrm{~g} \mathrm{TBT} \mathrm{L}^{-1}$. Intermediate and working solutions were diluted in seawater prior to each bioassay. Concentrations of the working solutions ranged from 20 to $137 \mu \mathrm{g}$ TBT $\mathrm{L}^{-1}$. All reported values are based on nominal concentrations as suggested by other authors (BUSHONG et al., 1988; OHJI et al., 2002). According to Bushong et al. (1988), nominal and measured concentrations of TBT in seawater bioassays typically agree within the range of $10-15 \%$. No light exposure and no feeding also contribute for maintenance of nominal concentrations during toxicity tests.

T. biminiensis has been cultivated at our laboratory for several generations (RIBEIRO; SOUZA-SANTOS, 2011). Seawater used in the cultivation and bioassays was collected at Barra de Sirinhaém beach $\left(08^{\circ} 35^{\prime} \mathrm{S}, 35^{\circ} 06^{\prime} \mathrm{W}\right)$, Pernambuco, Brazil. Copepods were cultivated in seawater filtered through 25 and $3 \mu \mathrm{m}$ cartridges with salinity $34 \pm 2$, temperature of $28 \pm 2^{\circ} \mathrm{C}$ and photoperiod of $12 / 12 \mathrm{~h}$ (dark/light) under constant aeration. Copepods were fed twice a week on diatoms (Thalassiossira 
weissflogii or Chaetoceros calcitrans) and Alconfish food. Diatoms were cultivated in $f / 2$ medium (ARAÚJO-CASTRO; SOUZA-SANTOS, 2005). Eight to eleven days prior to the bioassay, ovigerous females (>250 $\mu \mathrm{m}$ in length) were isolated from the maintenance cultures in order to produce nauplii. After $24 \mathrm{~h}$, the newly hatched nauplii were isolated for beginning a new culture with controlled age to be used as test animals in the bioassay.

In the bioassays, standard water quality parameters were as follows: salinity 34, dissolved oxygen $6 \pm 1 \mathrm{mg} \mathrm{L}^{-1}$ (saturation above $70 \%$ ), $\mathrm{pH} 8.1 \pm$ 0.1 and temperature $29 \pm 1{ }^{\circ} \mathrm{C}$. Toxicity tests were carried out according to the protocol described by Araújo-Castro et al. (2009), with modifications. Briefly, five bioassays were performed with adult (710 day old), ovigerous females of $T$. biminiensis. Exactly $10 \mathrm{~mL}$ of filtered seawater $(0.45 \mu \mathrm{m})$ was added to each glass container $(5 \mathrm{~cm}$ height $\mathrm{x} 3.5 \mathrm{~cm}$ diameter). Ten ovigerous females were carefully taken from the age-controlled cultures and placed in each of the containers. TBT working solutions were then added to the glass containers to yieldconcentrations ranging from 10 to $68 \mu \mathrm{g} \mathrm{TBT} \mathrm{L} \mathrm{L}^{-1}$ in $20 \mathrm{~mL}$ of seawater. Both controls (seawater only and seawater plus acetone) and treatments had four replicates each. Concentration of acetone in the test tubes did not exceed $24 \mu \mathrm{L} \mathrm{L}^{-1}$. The bioassays lasted for $48 \mathrm{~h}$ with no feeding and no light exposure. Dead test organisms were counted and removed at 24 and $48 \mathrm{~h}$. Mortality was typically defined as a position on which the animals urosome is perpendicular to its prosome (KWOK; LEUNG, 2005). In addition, no moving organisms were observed at the bottom of the recipients under a stereoscopic microscope after careful inspection. Copepods with no movement of both appendices and digestive system after an observation period of 30 seconds were also assumed to be dead.

The $24 \mathrm{~h}$ and $48 \mathrm{~h} \mathrm{LC}$ Lo were calculated according to the trimmed Spearman-Karber method (HAMILTON et al., 1977). The paired Students $t$-test was used to compare the mean mortality between controls. The no observed effect concentration (NOEC) and the lowest observed effect concentration (LOEC) were estimated using an Analysis of Variance (ANOVA) followed by the post hoc one-tailed Dunnetts test. The mortality data were transformed using arcsin function to meet the assumptions of the ANOVA (ZAR, 1999). Normality and homogeneity of variances were evaluated using the Lilliefors and Bartlett tests, respectively. The critical level of significance for all statistical analyses was set at 0.05 . Mortality in the controls averaged $0.12 \%$ and $0.25 \%$ for seawater only and seawater plus acetone, respectively. There was no significant difference in mortality between controls (paired $t$-test, $\mathrm{t}=-0.53, \mathrm{df}=$
$4, \mathrm{p}=0.62)$. This indicates that acetone used as a carrier solvent for TBT is non-toxic for $T$. biminiensis at a concentration of $24 \mu \mathrm{L} \mathrm{L}^{-1}$. Acetone seems to be slowly taken up by marine copepods (ARA et al., 2010). The lack of acetone toxicity is in agreement with the limit of $100 \mu \mathrm{L} \mathrm{L}^{-1}$ for bioassays (OECD, 2000). The median NOEC and LOEC after $48 \mathrm{~h}$ of exposure were 29 and $34 \mu \mathrm{g}$ TBT $\mathrm{L}^{-1}$, respectively. The NOEC for $T$. biminiensis was similar to that estimated for $T$. japonicus $\left(20 \mu \mathrm{g} \mathrm{L}^{-1}\right)$, indicating that these species have similar TBT sensitivities (LEE et al., 2007). The mean (1 standard deviation) 24 and 48 $\mathrm{h} \mathrm{LC}_{50}$ were $37 \pm 9$ and $36 \pm 9 \mu \mathrm{g}$ TBT $\mathrm{L}^{-1}$, respectively (Fig. 1).

$T$. biminiensis was as sensitive to TBT as other benthic copepods, including $T$. battagliai, $N$. spinipes and $T$. japonicus (KARLSSON et al., 2006; LEE et al., 2007; MACKEN et al., 2008; BAO et al., 2011). In general, these four benthic copepod species seem to be less sensitive to TBT than planktonic species such as $P$. marinus, A. tonsa, E. affinis and $S$. poplesia (Table 1). The lower sensitivity of benthic species may be related to more efficient detoxification mechanisms since they are usually exposed to higher concentrations of hydrophobic pollutants such as TBT. Alternatively, sensitivity differences between benthic harpacticoids and planktonic copepods (e.g., calanoids) may be a consequence of phylogenetic distances (DI TORO et al., 1991).

TBT is several orders of magnitude more toxic for $T$. biminiensis than ammonia $\left(24 \mathrm{~h} \mathrm{LC}_{50}\right.$ of $12,060 \mu \mathrm{g} \mathrm{L}^{-1}$ ) and chromium (48 $\mathrm{h} \mathrm{LC}_{50}$ of 7,510 $\mu \mathrm{g}$ $\mathrm{L}^{-1}$ ) (ARAÚJO-CASTRO et al., 2009). The average $24 \mathrm{~h} / 48 \mathrm{~h} \mathrm{LC}_{50}$ ratio for TBT is 1.0 . The calculated ratio for ammonia is 2.3 , whereas the $48 \mathrm{~h} / 72 \mathrm{~h} \mathrm{LC}_{50}$ ratio for chromium is 1.6 (ARAÚJO-CASTRO et al., 2009). These ratios suggest that $T$. biminiensis takes up organic contaminants such as TBT faster than inorganic contaminants such as ammonia and chromium. As a consequence, TBT seems to reach a steady-state in $T$. biminiensis within $24 \mathrm{~h}$ of exposure while ammonia and chromium may not reach a steadystate even after $72 \mathrm{~h}$ of exposure. The TBT lipophilic nature and the high lipid content of $T$. biminiensis ( $\sim 35 \%$ dry weight) may facilitate the pollutant uptake (LIMA et al., 2013).

In summary, $T$. biminiensis was as sensitive to TBT as other benthic copepod species including $T$. battagliai, T. japonicus and N. spinipes. Nonetheless, benthic copepods are generally less sensitive to TBT pollution than planktonic copepods. T. biminiensis is several orders of magnitude more sensitive to TBT thanother inorganic contaminants such as ammonia and chromium. T. biminiensis also seems to absorb organic contaminants (e.g., TBT) faster thaninorganic contaminants. 


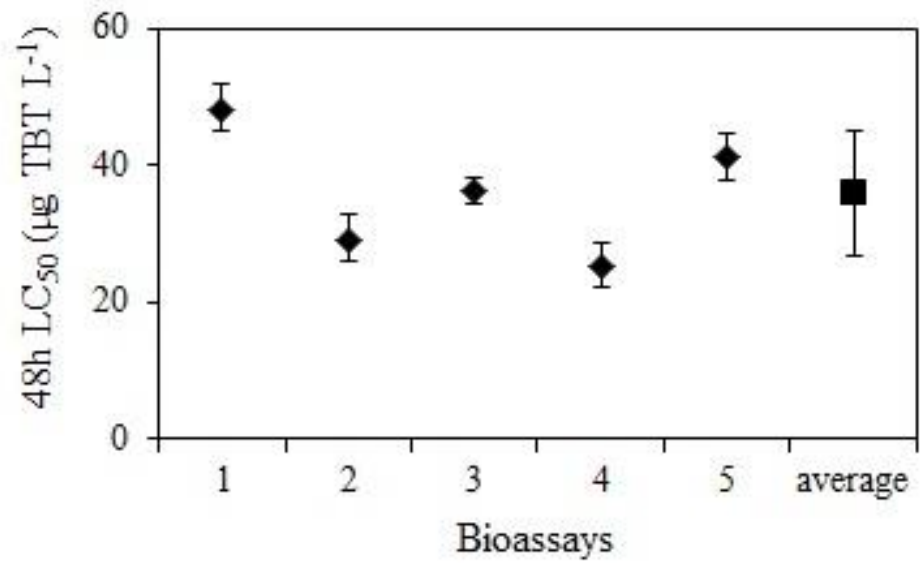

Fig. 1. Lethal concentrations for $50 \%$ of the test animals (i.e., ovigerous females of Tisbe biminiensis) after 48 hours of exposure to tributyltin (TBT). Error bars for square and diamonds represent the coefficient of variation and the $95 \%$ confidence intervals, respectively.

Table 1.Sensitivity of several copepod species to tributyltin (TBT) based on lethal concentrations ( $\mu \mathrm{g}$ TBT $\mathrm{L}^{-1}$ ) for $50 \%$ of the test animals $\left(\mathrm{LC}_{50}\right)$ after the exposure time.

\begin{tabular}{lcccl}
\hline \hline Species & $\begin{array}{c}\text { Life } \\
\text { Stage }\end{array}$ & $\begin{array}{c}\mathrm{LC}_{50} \\
(\mu \mathrm{g} \mathrm{TBT} \mathrm{L})^{-1}\end{array}$ & $\begin{array}{c}\text { Exposure } \\
\text { (days) }\end{array}$ & Reference \\
\hline $\begin{array}{l}\text { Benthic copepods } \\
\text { Tisbe biminiensis }\end{array}$ & Adult & 36 & 2 & This study \\
Tisbe battagliai & Copepodite & 17 & 2 & Macken et al. (2008) \\
Nitocra spinipes & Adult & 1,96 & 4 & Linden et al. (1979) \\
& Adult & 12,7 & 4 & Karlsson et al. (2006) \\
Tigriopus japonicus & Adult & 1,88 & 4 & Linden et al. (1979) \\
& Adult & 50 & 4 & Lee et al. (2007) \\
& Adult & 18 & 4 & Bao et al. (2011) \\
& Adult & 0,85 & 2 & Ara et al. (2010) \\
& Adult & 0,51 & 2 & Ara et al. (2010) \\
& Adult & 0,15 & 4 & Kwok and Leung (2005) \\
Planktonic copepods & & & & \\
Pseudodiaptomus marinus & Adult & 1,2 & 2 & Huang et al. (2006) \\
Acartia tonsa & Adult & 0,98 & 4 & U'renet al. (1983) \\
& Adult & 0,24 & 2 & Kusk and Petersen (1997) \\
& Subadult & 1,1 & 2 & Bushong et al. (1988) \\
Eurytemora affinis & Subadult & 2,2 & 2 & Hall et al. (1988) \\
& Subadult & 2,5 & 2 & Bushong et al. (1988) \\
Schmackeria poplesia & Subadult & 1,4 & 2 & Bushong et al. (1988) \\
& Adult & 0,41 & 4 & Huang et al. (2010) \\
\hline
\end{tabular}

ACKNOWLEDGEMENTS

B. V. M. Costa was funded by Conselho Nacional de Desenvolvimento Científico e Tecnológico (CNPq), Ministry of Science and Technology, Brazil.

\section{REFERENCES}

ALZIEU, C. L.; SANJUAN, J.; DELTREIL, J. P.; BOREL, M. Tin contamination in Arcachon Bay: effects on oyster shell anomalies. Mar. Pollut. Bull., v. 17, n. 11, p. 494498, 1986. 
ANTIZAR-LADISLAO, B. Environmental levels, toxicity and human exposure to tributyltin (TBT)-contaminated marine environment: a review. Environ. Int., v. 34, n. 2, p. 292-308, 2008.

AONO, A.; TAKEUCHI, I. Effects of tributyltin at concentrations below ambient levels in seawater on Caprella danilevskii (Crustacea: Amphipoda: Caprellidae). Mar. Pollut. Bull., v. 57, n. 6/12, p. 515523, 2008.

ARA, K.; FUJITA, Y.; HIROMI, J.; UCHIDA, N. Acute and subchronic toxicity of tributyltin chloride (TBTCl) to the marine harpacticoid copepod Tigriopus japonicus Mori. J. Water Environ. Technol., v. 8, n. 4, p. 293-303, 2010.

ARAÚJO-CASTRO, C. M. V.; SOUZA-SANTOS, L. P. Are the diatoms Navicula sp. and Thalassiosira fluviatilis suitable to be fed to the benthic harpacticoid copepod Tisbe biminiensis? J. Exp. Mar. Biol. Ecol., v. 327, n. 1, p. 58-69, 2005.

ARAÚJO-CASTRO, C. M. V.; SOUZA-SANTOS, L. P.; TORREIRO, A. G. A. G.; GARCIA, K. S. Sensitivity of the marine benthic copepod Tisbe biminiensis (Copepoda, Harpacticoida) to potassium dichromate and sediment particle size. Braz. J. Oceanogr., v. 57, n. 1, p. 33-41, 2009.

BAO, V. W. W.; LEUNG, K. M. Y.; QIU, J.-W.; LAM, M. H. W. Acute toxicities of five commonly used antifouling booster biocides to selected subtropical and cosmopolitan marine species. Mar. Pollut. Bull., v. 62, n. 5, p. 1147-1151, 2011.

BIGATTI, G.; PRIMOST, M. A.; CLEDON, M.; AVERBUJ, A.; THEOBALD, N.; GERWINSKI, W.; ARNTZ, W.; MORRICONI, E.; PENCHASZADEH, P. E. Biomonitoring of TBT contamination and imposex incidence along $4700 \mathrm{~km}$ of Argentinean shoreline (SW Atlantic: From 38S to 54S). Mar. Pollut. Bull., v. 58, n. 5, p. 695-701, 2009.

BUSHONG, S. J.; HALL Jr., L. W.; SCOTT HALL, W.; EDWARD JOHNSON, W.; HERMAN, R. L. Acute toxicity of tributyltin to selected Chesapeake Bay fish and invertebrates. Water Res., v. 22, n. 8, p. 1027-1032, 1988.

CCME.Canadian Water Quality Guidelines for the protection of aquatic life - Organotin. Canada: Canadian Council of Ministers of the Environment, 1999.

CEC.Directive of the European Parliament and of the Council on environmental quality standards in the field of water policy and amending directive: $n$. 2006/0129. Belgium: Commission of the European Communities, 2006.

CHAMP, M. A. The status of the treaty to ban TBT in marine antifouling paints and alternatives. In: UJNR (US/JAPAN) MARINE FACILITIES PANEL MEETING, 24., Hawaii, 2001. Proceedings. Virginia: Advanced Technology Research Project Corporation, 2001.

CONAMA. Resolução 357, de 17 de março de 2005. Classificação dos corpos de agua e diretrizes ambientais para o seu enquadramento, bem como estabelece as condições e padrões de lançamento de efluentes, e da outras providências. Conselho Nacional de Meio Ambiente, Brasília, 2005.
DI TORO, D. M.; ZARBA, C. S.; HANSEN, D. J.; BERRY, W. J.; SWARTZ, R. C.; COWAN, C. E.; PAVLOU, S. P.; ALLEN, H. E.; THOMAS, N. A.; PAQUIN, P. R. Technical basis for establishing sediment quality criteria for nonionic organic chemicals using equilibrium partitioning. Environ. Toxicol. Chem., v. 10, n. 12, p. 1541-1583, 1991.

HALL, L. W.; BUSHONG, S. J.; HALL, W. S.; JOHNSON, E. Acute and chronic effects of tributyltin on a Chesapeake Bay copepod. Environ. Toxicol. Chem., v. 7, p. 41-46, 1988.

HAMILTON, M. A.; RUSSO, R. C.; THURSTON, R. V. Trimmed Spearman-Karber method for estimating median lethal concentration in toxicity bioassays.Environ. Sci. Technol., v. 11, n. 7, p. 714719, 1977.

HUANG, Y.; ZHU, L.; LIU, G. The effects of bis(tributyltin) oxide on the development, reproduction and sex ratio of calanoid copepod Pseudodiaptomus marinus. Estuarine, Coastal Shelf Sci., v. 69, n. 1/2, p. 147-152, 2006

HUANG, Y.; ZHU, L.; QIU, X.; ZHANG, T. Effect of bis(tributyltin) oxide on reproduction and population growth rate of calanoid copepod Schmackeria poplesia. Chin. J. Oceanol. Limnol., v. 28, n. 2, p. 280-287, 2010.

IMO. International convention on the control of harmful anti-fouling systems on ships. London: International Maritime Organization, 2001.

IMO. Status of Conventions. London: International Maritime Organization. Available on: www.imo.org/about/conventions. Accessed in: 19 nov. 2012.

KARLSSON, J.; BREITHOLTZ, M.; EKLUND, B.A practical ranking system to compare toxicity of antifouling paints.Mar. Pollut. Bull.,v. 52, n. 12, p. 16611667,2006

Kusk, K. O.; PETERSEN, S. Acute and chronic toxicity of tributyltin and linear alkylbenzenesulfonate to the marine copepod Acartia tonsa.Environ. Toxicol.Chem., v. 16, n. 8, p. 1629-1633, 1997.

KWOK, K. W. H.; LEUNG, K. M. Y. Toxicity of antifouling biocides to the intertidal harpacticoid copepod Tigriopus japonicus (Crustacea, Copepoda): effects of temperature and salinity. Mar. Pollut. Bull., v. 51, n. 8/12, p. 830837, 2005.

LEE, K. W.; RAISUDDIN, S.; HWANG, D. S.; PARK, H. G.; LEE, J. S. Acute toxicities of trace metals and common xenobiotics to the marine copepod Tigriopus japonicus: evaluation of its use as a benchmark species for routine ecotoxicity tests in Western Pacific coastal regions. Environ. Toxicol., v. 22, n. 5, p. 532$538,2007$.

LIMA, L. C. M.; NAVARRO, D. M. A. F.; SOUZASANTOS, L. E. Effect of diet on the fatty acid composition of the copepod Tisbe biminiensis. J. Crustacean Biol., v. 33, n. 3, p. 372-381, 2013.

LINDEN, E.; BENGTSSON, B. E.; SVANBERG, O.; SUNDSTROM, G.; NATIONAL SWEDISH ENVIRONMENT PROTECTION. The acute toxicity of 78 chemicals and pesticide formulations against two brackish water organisms, the bleak (Alburnus alburnus) and the harpacticoids Nitocra spinipes.Chemosphere, v. 8, n. 11/12, p. 843-851, 1979. 
LIU, L. -L.; WANG, J. -T.; CHUNG, K. -N.; LEU, M. -Y.; MENG, P. -J. Distribution and accumulation of organotin species in seawater, sediments and organisms collected from a Taiwan mariculture area. Mar. Pollut. Bull., v. 63, n. 5/12, p. 535-540, 2011.

MACKEN, A.; GILTRAP, M.; FOLEY, B.; MCGOVERN, E.; MCHUGH, B.; DAVOREN, M. A model compound study: the ecotoxicological evaluation of five organic contaminants employing a battery of marine bioassays. Environ. Pollut., v. 153, n. 3, p. 627-637, 2008.

MARTÍ, N.; AGUADO, D.; SEGOVIA-MARTÍNEZ, L.; BOUZAS, A.; SECO, A. Occurrence of priority pollutants in WWTP effluents and Mediterranean coastal waters of Spain. Mar. Pollut. Bull., v. 62, n. 3, p. 615625, 2011.

OECD. Guidance document on aquatic toxicity testing of difficult substances and mixtures. Paris: Organization for Economic Co-operation and Development, 2000.

OHJI, M.; TAKEUCHI, I.; TAKAHASHI, S.; TANABE, S.; MIYAZAKI, N. Differences in the acute toxicities of tributyltin between the Caprellidea and the Gammaridea (Crustacea :Amphipoda). Mar. Pollut. Bull., v. 44, n. 1, p. $16-24,2002$.
RADKE, B.; WASIK, A.; JEWELL, L. L.; PIKETH, S.; PACZEK, U.; GALUSZKA, A.; NAMIESNIK, J. Seasonal changes in organotin compounds in water and sediment samples from the semi-closed Port of Gdynia. Sci. Total Environ., v. 441, p. 57-66, 2012.

RIBEIRO, A. C. B.; SOUZA-SANTOS, L. P. Mass culture and offspring production of marine harpacticoid copepod Tisbe biminiensis. Aquaculture, v. 321, n. 3/4, p. 280288, 2011.

U'REN, S. C. Acute toxicity of (bis)tributyltin oxide to a marine copepod. Mar. Pollut. Bull., v. 14, n. 8, p. 303306, 1983.

VOLKMANN-ROCCO, B. Tisbe biminiensis (Copepoda, Harpacticoida) a new species of the Gracilisgroup.Arch. Oceanogr. Limnol., v. 18, p. 71-90, 1973.

ZAR, J. H. Biostatistical analysis. 4. ed. Upper Saddle River: Prentice Hall; London: Prentice Hall International, 1999. $123 \mathrm{p}$.

(Manuscript received 28 January 2014; revised 15 March 2014; accepted 21 March 2014) 